\title{
Two Number Addition Using Drinking Straws And Number Bags In The First Grade Of MI Muhammadiyah Pondok Karanganom Klaten
}

\author{
Aulia Nur Handayani \\ UIN Sunan Kalijaga Yogyakarta \\ Jl. Laksda Adisucipto, Papringan, Caturtunggal, Kec. Depok, Kabupaten Sleman, \\ Daerah Istimewa Yogyakarta 55281 \\ auliau89@gmail.com \\ Fitri Yuliawati \\ UIN Sunan Kalijaga Yogyakarta \\ Jl. Laksda Adisucipto, Papringan, Caturtunggal, Kec. Depok, Kabupaten Sleman, \\ Daerah Istimewa Yogyakarta 55281 \\ fitriyulia50@gmail.com
}

\begin{abstract}
This study aimed to determine the application and improvement of learning outcomes by drinking straws and bag numbers in learning the addition of two numbers. This research was a classroom action research conducted in class I B of MI Muhammadiyah Pondok Academic Year 2018/2019, totaling 25 students. This research was conducted in 2 cycles consisting of four stages, namely planning, action, observation, and reflection. This study used drinking straws and bag numbers as learning media. The instruments used in this study were RPP, LKPD, guidelines for observation and interviews and documentation. The indicator of the success of this study was in terms of the process of teacher and student abilities observed aspects of $80 \%$ or 7 of the 8 aspects and in terms of results of $80 \%$ or 20 of the 25 class, I B students completed the passing grade, which was 65 . The results showed that drinking straws and number bags were able to facilitate students in learning the two numbers addition material and were able to improve student learning outcomes, indicated by learning outcomes that reached KKM in cycles I and II were $68 \%$ and $84 \%$. The application of drinking straws and number bags could improve the learning outcomes of class I B students at MI Muhammadiyah Pondok Karanganom Klaten.
\end{abstract}

Keywords: addition, drinking straws, number bag

\section{Abstrak}

Penelitian ini bertujuan untuk mengetahui penerapan dan meningkatkan hasil belajar dengan media sedotan (drinking straws) dan kantong bilangan dalam pembelajaran materi penjumlahan dua bilangan. Penelitian ini merupakan Penelitian Tindakan Kelas dengan subjek siswa kelas I B MI Muhammadiyah Pondok Tahun Ajaran 2018/2019, yang berjumlah 25 siswa. Penelitian ini 
diadakan dalam 2 siklus yang terdiri dari empat tahap, yaitu perencanaan, tindakan, observasi dan refleksi. Penelitian ini menggunakan media drinking straws dan kantong bilangan. Instrumen yang digunakan dalam penelitian ini adalah RPP, LKPD, pedoman observasi dan wawancara serta dokumentasi. Indikator keberhasilan penelitian ini adalah dari segi proses kemampuan guru dan siswa aspek yang diamati sebesar 80\% atau 7 dari 8 aspek dan dari segi hasil sebesar 80\% atau 20 dari 25 siswa kelas I B tuntas pada nilai KKM, yaitu 65. Hasil penelitian menunjukkan bahwa pembelajaran dengan media drinking straws dan kantong bilangan mampu memudahkan siswa dalam mempelajari materi penjumlahan dua bilangan dan mampu meningkatkan hasil belajar siswa, ditunjukkan oleh hasil belajar yang mencapai KKM pada siklus I dan II adalah $68 \%$ dan 84\%. Dengan ini, dapat disimpulkan bahwa penerapan media drinking straws dan kantong bilangan mampu meningkatkan hasil belajar siswa kelas I B MI Muhammadiyah Pondok Karanganom Klaten.

Kata kunci: penjumlahan, sedotan (drinking straws), kantong bilangan

\section{Introduction}

Mathematics is one way to find answers to problems that occur in humans, a way that uses information, uses knowledge about shapes and sizes, uses the ability to calculate the most important is related to human beings themselves in seeing and using relationships. ${ }^{1}$ Mathematics itself is useful for human life. For this reason, mathematics is important to be taught in elementary school. Basic mathematics starts with a variety of physical activities, such as counting and grouping objects. ${ }^{2}$

Counting activities, usually called addition, are the initial part that will affect the cognitive development of students, these activities can be found every day and everywhere. ${ }^{3}$ The importance of the development of arithmetic for elementary school students in early grades because of the proximity of counting activities to life. In the development of mathematical abilities, students are required to master the concepts

1 Mulyono Abdurrahman, Pendidikan Bagi Anak Berkesulitan Belajar (Jakarta: Rineka Cipta, 2000), page 12.

2 Dwi Ernawati, "Peran Guru Kelas Dalam Mengatasi Kesulitan Belajar Matematika Pada Siswa Kelas III Di SD Negeri Suryodiningrat I Yogyakarta," Universitas PGRI Yogyakarta, n.d., page 2.

3 Rosma Hartiny Sam's, Model Penelitian Tindakan Kelas Teknik Bermain Konstuktif Untuk Peningkatan Hasil Belajar Matematika (Yogyakarta: Sukses Offset, 2010), page 2. of numbers and symbols, the numbers that form the basis of science. ${ }^{4}$ To develop mathematical abilities can be done by using appropriate media.

Intermittent and uninterrupted learning will cause a poor understanding of a concept, therefore students' success in absorbing mathematics at the elementary school level becomes a mirror for success in the next level of mathematics. ${ }^{5}$ The world of mathematics for the world of science acts as a symbolic language that enables the realization of accurate and accurate communication. ${ }^{6}$

The development of mathematics learning outcomes is very important for students. ${ }^{7}$ Developing mathematics learning outcomes for students by introducing students to the symbol of numbers, addition, and subtraction, division and multiplication simply. ${ }^{8}$ With the effort of innovation in learning mathematics is not taught routinely to practice or memorize formulas but presents simple and fun mathematical material so that it can be easily understood by students. To present mathematics in a

\footnotetext{
4 Ibid.

${ }^{5} \mathrm{Ibid}$, page 14 .

6 Jujun S. Suriasumantri, Filsafat Ilmu Sebuah Pengantar Populer (Jakarta: Sinar Harapan, 2005), page 203.

7 Hartiny Sam's, Model Penelitian Tindakan Kelas Teknik Bermain Konstuktif Untuk Peningkatan Hasil Belajar Matematika, page 3.

8 Ibid.
} 
pleasant atmosphere so that students are motivated to learn mathematics, some efforts can be made by the teacher to attract students' attention and motivation in learning, one of them is by using media. Using appropriate media is the right thing to teach the material to mathematics into easy and fun lessons so students don't get bored easily.

Mathematics is a symbolic language whose practical function is to express quantitative relations and spaces while the theoretical function is to facilitate thinking. ${ }^{9}$ Mathematics has an important role in advancing human thought and various disciplines which are the basic sciences of modern technology development. ${ }^{10}$ According to Hans Freudenthal in the book, Zubaidah Amir and Risnawati argued that mathematics is a way of thinking logically that is presented in numbers, spaces, and forms with existing rules that cannot be separated from the activities of these people. ${ }^{11}$

Mathematics subjects need to be given to students from primary schools, of course, they have goals, which are to equip students with the ability to think logically, analysis, systematically, critically and creatively, and the ability to work together. ${ }^{12}$

Mathematics learning is a process of teaching and learning that can improve the ability to construct new knowledge to improve good mastery of mathematical material built by the teacher and be able to improve students 'thinking abilities to develop students' thinking creativity. ${ }^{13}$ In

9 Hartiny Sam's, Model Penelitian Tindakan Kelas Teknik Bermain Konstuktif Untuk Peningkatan Hasil Belajar Matematika, page 11.

10 Ibrahim and Suparni, Pembelajaran Matematika theory dan Aplikasinya (Yogyakarta: SUKAPress UIN Sunan Kalijaga, 2012), hlm. 35.

11 Zubaidah Amir and Risnawati, Psikologi Pembelajaran Matematika (Yogyakarta: Aswaja Pressindo, 2016), page 9.

12 Ibid.

13 Amir, Psikologi Pembelajaran Matematika, page 8 . the process of learning mathematics, both teachers and students together become the perpetrators of the implementation of learning objectives. ${ }^{14}$ Learning objectives will achieve maximum results if learning is carried out effectively, which means involving all students to be active.

During the process of learning, mathematics is taught by emphasizing the nature of memorization especially partially, the possibility of students to have a high level of mathematical ability is small. ${ }^{15}$ For this reason, efforts to find the best way to convey various concepts taught in schools need to be done immediately. ${ }^{16}$ With this, teachers are expected to be able to choose and use media or better learning models so that they can overcome student learning difficulties.

Specific learning difficulties are a disorder that involves understanding and using spoken or written language in one or more of the basic psychological processes. ${ }^{17}$ The form of this difficulty is a form of difficulty listening, thinking, speaking, reading, writing, spelling, or counting. The phenomenon of students' mathematics learning difficulties is usually seen from the decline in learning achievement. ${ }^{18}$ Learning difficulties can also be evidenced by the emergence of student behavior such as not paying attention, the joy of shouting and playing with friends in class, fighting, and skipping class hours of mathematics.

According to Dwi Yuniarto, the number bag is a simple tool aimed at making it easier for students to understand the

\footnotetext{
${ }^{14}$ Ibid.

${ }^{15}$ Pembelajaran Matematika theory dan Aplikasinya, page 35 .

16 Ibid.

17 Amir, Psikologi Pembelajaran Matematika, page 186.

${ }^{18}$ Ibid, page 192.
} 
arithmetic operations in mathematics. ${ }^{19}$ This number of bag media is rectangular with many boxes attached or called a number bag. This media serves as a determinant of the value of a number, namely units, tens, hundreds and thousands. With the grouping of values of a number, it will be easier for students to do the sum calculation operations. Drinking straws or straws on this media is used as a determinant of the number of a number. If one straw is placed in a bag that is worth thousands, then the value of one straw is one thousand. Likewise, if the straw is placed in a pocket of hundreds of places, then one straw is worth one hundred and so on. ${ }^{20}$

Advantages and Disadvantages of Drinking Straws and Number Bags

The advantages of drinking straws media and number bags are: ${ }^{21}$ 1) Helping teachers to convey learning material more interestingly; 2) Helping the teacher to be able to convey an abstract learning concept into a real situation; 3) Strengthening students' knowledge in understanding the place value of a number; and 4) Helping students to solve problem arithmetic operations systematically.

Meanwhile, the weakness of the number bag media is that it cannot be used in learning to count involving negative or decimal numbers. ${ }^{22}$

19 Devi Ratnasari, "Pengaruh Penggunaan Media Kantong Bilangan Terhadap Hasil Belajar Matematika Penjumlahan Bilangan Secara Bersusun", Jurnal Pendidikan Guru Sekolah Dasar Edisi 27 Tahun ke-5 2016, page 2 .

${ }^{20}$ Mayasa, Media Pembelajaran Sedotan (Drinking Straws) dan Kantong Bilangan, Dalam Laman, m4y-a5a.blogspot.com/2012/04/mediapembelajaran-sedotan-dringking-html? $\mathrm{m}=1$, taken on 5 January 2019 at 19:30 WIB.

${ }^{21}$ Ibid.

22 Ibid.

\section{Equipment Used}

The tools used to make drinking straws media and number bags are Several transparent plastic bags as storage pockets attached to a sheet of asturo paper and Straws. ${ }^{23}$

\section{Demonstration Steps}

An example will be the result of the sum of two numbers $26+37=\ldots$, or if written down is:

\section{6 \\ $\underline{37}+$}

1. Insert the straw in a plastic bag according to the desired number, which is 2 dozens and 6 units for the number 26 .

2. Enter 3 dozens and 7 units for the number 37.

3. Students are instructed to name the number indicated by the number of straws in paper pockets.

4. Students then combine the straws according to their place scores. Combine the units with the units first, so you will get as many as 13 . Straws. Furthermore, the 13 straws taken 10 straws tied as 1 dozen, which are then stored in dozens of storage pockets. The rest put it in the unit pocket.

5. For tensile yields, join a straw in a storage pocket and two tens pockets, then place it in the tens-down pocket below.

6. Count the number of straws in the yield pocket.

7. Students then write down the results of the answers obtained.

23 Heruman, Model Pembelajaran Matematika Di Sekolah Dasar (Bandung: PT. Remaja Rosdakarya, 2017), page 8 . 


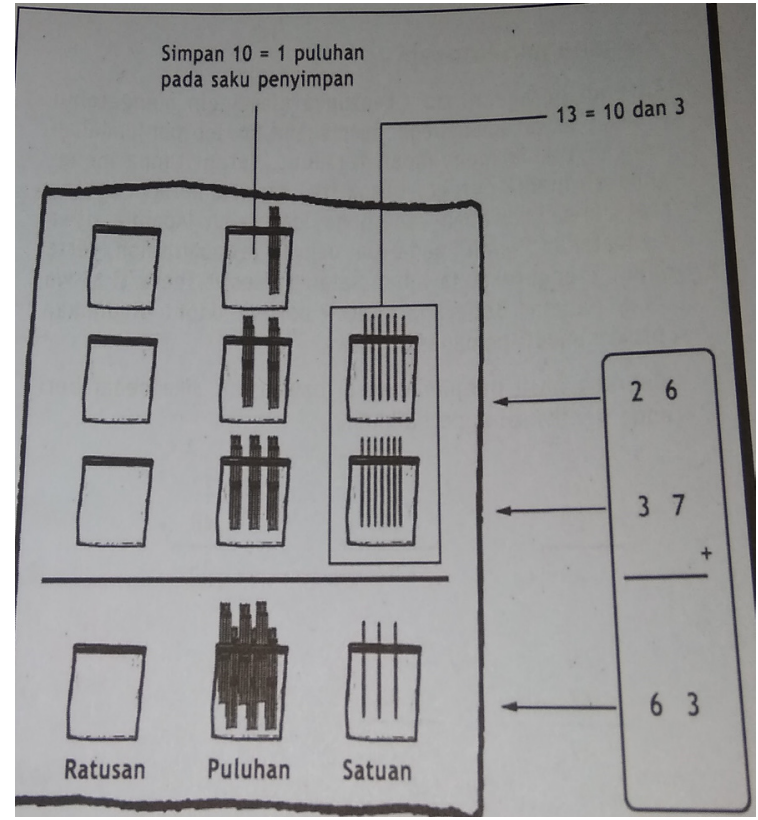

Figure 1. Drinking Straws and Number Bags

8. For students to understand, this activity should be repeated several times with different numbers. This can be done with the guidance of the teacher or tried by students both in groups and individually.

9. For further activities, students are given examples of questions without using learning media but can be helped with a storage box.

In fact, mathematics learning class I B MI Muhammadiyah Pondok Klaten only uses blackboard media without using other media. So the results of learning mathematics, especially the sum of two numbers with saving techniques have not achieved good results. In learning, mathematics must be carried out continuously from the most fundamental concepts to higher concepts. ${ }^{24}$ Someone will have difficulty learning a concept in mathematics if there are things that are not mastered. Difficulty learning in students in the class I B MI Muhammadiyah Pondok Klaten is students who do not understand the value of a place and some students are still having difficulty reading.

\footnotetext{
${ }^{24}$ Ibid, page 13 .
}

Based on the results of the prestudy showed that the learning outcomes of students the sum of two numbers with the saving technique in class I B was still low or below the minimum mastery criteria value of $65 . .^{25}$

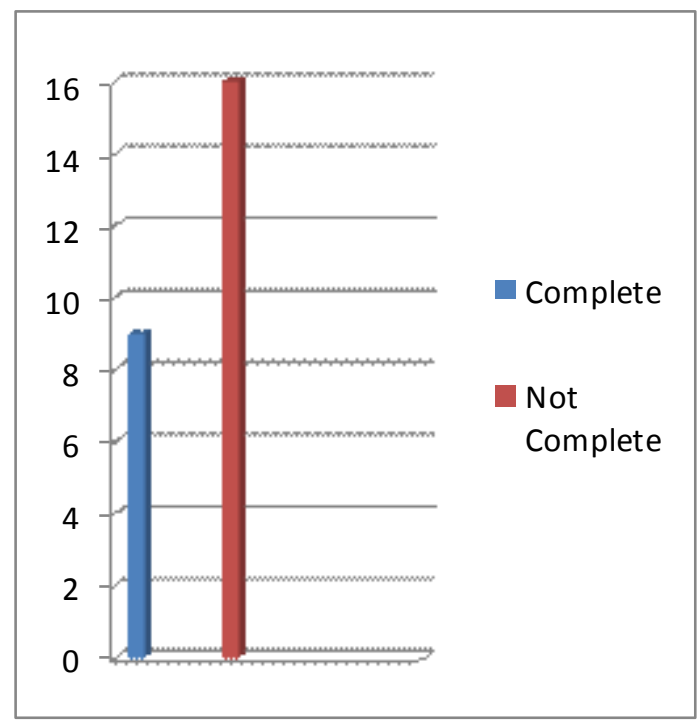

Diagram 1. Student Learning Outcomes Before Action

The results of this pre-study show that the grades of 9 students have met the KKM while 16 students under the minimum mastery criteria with grades that are still low. According to information from the guardian of class, I B namely Mrs. Sri Muriningsih, S. Pd. I. said that children's learning outcomes are still low because it is still in the learning process. ${ }^{26}$ After that, the researcher made observations on the learning process of class I B. The results of observations made by researchers in the framework of the research process showed the process of learning mathematics in class I B encountered problems related to the learning process.

One problem is that students tend to play alone or with their classmates and do not pay attention to the teacher when explaining the material. If the teacher appoints one

${ }^{25}$ Pre-Research Results in Class I B MIM Pondok Karanganom, January 22, 2019.

26 Interview with Ms. Sri Muriningsih, Class I B MIM teacher at Pondok Karanganom, January 8, 2019. 
student to answer the question, only that student pays attention to the teacher while the other student does not pay attention. Even though the teacher has applied methods such as group discussions, only a few students are active. Other problems are also caused by the teacher not using instructional media, so students pay less attention that makes student learning outcomes low. ${ }^{27}$ This is consistent with information from some students that the way to teach teachers is still using the lecture method and only using the blackboard media without media or other teaching aids. ${ }^{28}$

Students are not yet right in adding two numbers with the saving technique, because 16 students or students who have not yet completed the minimum mastery criteria do not yet know how to add up with the saving technique. With the results of numbers that should be stored as tens but students immediately write as the results of the sum. This teacher must be able to innovate the teaching methods and media used, to be able to involve students directly in the learning process. With this students do not have free time or opportunity just to play with friends and can focus students in the learning process. An alternative learning strategy for students directly involved during the learning process is to implement learning by using media or teaching aids that involve students to be active in learning. It is expected that with this media or teaching aids, the learning outcomes of Class I B MI Muhammadiyah Pondok Karanganom will improve, the classroom atmosphere is more conducive and creates a pleasant and not boring learning environment for mathematics.

27 Observation of Mathematics Learning Process Class 1 B MIM Pondok Karanganom, January 14, 2019.

28 Interview with MIM Pondok Karanganom Class I B Students, January 22, 2019.
Media number bags are often used by the media for addition as a place of numbers and not only drinking straws or straws used to determine the number of numbers but can also use seeds, sticks, pencils, etc. Researchers choose to use drinking straws here because they are not harmful to students and can make it easier to calculate the number of numbers to be worked on. Other media such as addition boards with number cards can also be used in learning to add two numbers but this medium cannot teach students to count numbers because numbers are written on cards. So the child does not count the number of numbers to be counted.

Based on the description above, the researcher is interested in researching, "Addition of Two Numbers with Media Drinking Straws and Pouches of Class I MI Muhammadiyah Pondok Karanganom". This research was conducted to find out the application of drinking straws media and number bags in mathematics learning of the addition of two numbers and to know the increase in student learning outcomes in mathematics learning of the sum of two numbers with drinking straws media and number bags of class I MI Muhammadiyah Karanganom Klaten students.

\section{Method}

This research used the Classroom Action Research (CAR) method. Classroom Action Research is a research conducted by teachers in their class by designing, implementing, and reflecting collaborative and participatory actions to improve their performance as teachers so that the learning process becomes better. ${ }^{29}$

Research Subjects are the main source of research data. The subjects in this study are

29 Fitri Yuliawati, Jamil Suprihatiningsah, and M. Agung Rokhimawan, Penelitian Tindakan Kelas Untuk Tenaga Pendidik Professional (Yogyakarta: Pedagogia, 2012), page 14. 
the students in class I B MI Muhammadiyah Pondok, Karanganom, Klaten, amounting to 25 students, 11 male students, and 14 female students, I B class teacher as a collaborator.

The material discussed in this study is the sum of two numbers with saving techniques.

Data collection techniques in this study were observation, interviews, written tests, and documentation. The research instruments in this thesis are the learning implementation plan, student worksheet, observation and interview guidelines, and documentation.

In this classroom action research, descriptive qualitative analysis was used. There are two types of data collected in this class action research, namely qualitatively and quantitatively. Qualitative data that is describing the reality obtained during the learning process takes place. While the quantitative data is the value of student learning outcomes in class I B to analyze the level of success or percentage of students' mastery learning. Researchers use descriptive statistics that look for percentages and present data that is easy to read using diagrams and tables. Look for percentages by:

1. Learning Process:

Percentage $=\sum$ Appropriate aspects $\times 100 \%$

$$
\sum \text { Observed aspects }
$$

2. Learning Outcomes:

Percentage $=\frac{\sum \text { Students complete } \quad \text { KKM }}{\sum \text { Students in grade 1 } \mathrm{B}}$

\section{Findings and Discussion}

Cycle I shows that the ability of teachers and students is $87.5 \%$ or as many as 7 of the 8 aspects observed. Student learning outcomes indicate that at the end of the first cycle, students who have achieved minimal mastery learning as many as 17 students (68\%), while 8 other students (32\%) have not reached mastery learning minimum.
Cycle II shows the results of the ability of teachers in learning cycle II of $100 \%$ or as many as 8 of the 8 aspects observed. As for the ability of students the results obtained were $87.5 \%$ or 7 of the 8 aspects observed. Student learning outcomes show that at the end of the second cycle students who reached minimal mastery criteria were 21 students (84\%) and students who did not complete minimal mastery criteria were 4 students $(16 \%)$.

\section{The Implementation of Learning by Using Drinking Straws and Number Bags}

Learning mathematics plays an important role in human life. Basic mathematics starts with counting and grouping objects. Counting activities are the initial part that will affect the cognitive development of students, these activities can be found every day and everywhere. ${ }^{30}$ The importance of the development of arithmetic for elementary school students in early grades because of the proximity of counting activities to life. With this application of learning to count with the media drinking straws and number bags to facilitate students learning.

In this study, the implementation of learning by using drinking straws media and number bags begins with the teacher explaining how to use the media so that students become interested in trying to count two numbers with the media. The advantage of these media is that students can place the value of a number and count two numbers by storing techniques properly and correctly. Learning is not easy to get bored and students are more interested in learning by using drinking straws media and number bags compared to just the blackboard media, so

30 Hartiny Sam's, Model Penelitian Tindakan Kelas Teknik Bermain Konstuktif Untuk Peningkatan Hasil Belajar Matematika, page 2. 
students become easier to work on problems. The teacher can activate students when the learning process uses drinking straws media and the number of bags. With the results of observations showing the results of the ability of teachers and students are as follows:

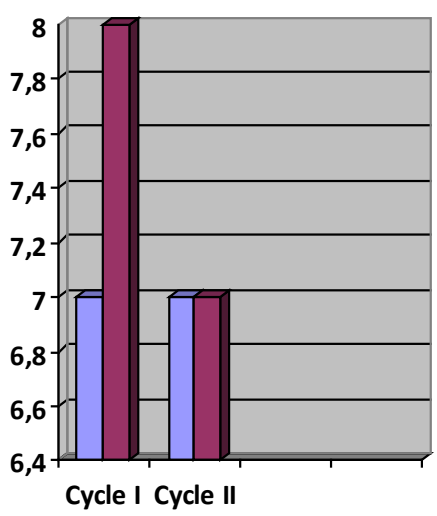

$\square$ Teacher's Ability $\square$ Student's Ability

Diagram 2. Comparison Diagram of Teacher and Student Ability in Cycle I and II

At the end of the second cycle, the researcher interviewed the class I B teacher and class I B students, which contained the learning of adding two numbers with drinking straws media and number bags. From the results of this interview can find out how the responses from teachers and students and know how to learn after using the drinking straws media and number bags.

The results of the interview with the teacher that students assume that mathematics is a difficult subject, students are interested and curious about what is drinking straws media and number bags, students also look excited when learning with these media. Students also easily accept learning with this media. This can be proven by when the learning takes place the teacher asks students to come to the front of the class to work on the problem, with most enthusiastic students pointing fingers which means they want to work on the problem in front of the class with drinking straws and number bags. ${ }^{31}$

${ }^{31}$ Interview with Ms. Sri Muriningsih Teacher I B MIM Pondok Karanganom, March 20, 2019.
The results of interviews with students that students are interested in when learning by using drinking straws and number bags as said by the teacher, the learning process becomes more fun, and this media makes it easy for students to work on problems marked by increasing student learning outcomes. ${ }^{32}$

\section{Student's Learning Outcomes Using Drinking Straws and Number Bags}

By using drinking straws media and number bags in learning two numbers, actively involving students and practicing directly using the media with the guidance of the teacher. Active student involvement and direct practice of the media are expected to increase students' understanding.

The application of drinking straws media and the number of bags in each cycle turned out to be able to improve student learning outcomes. MI Muhammadiyah Pondok Karanganom has set the KKM for mathematics, which is 65 . With the application of this media it can be seen the number of students who complete the KKM in the first cycle was 17 students $(68 \%)$ and in the second cycle were 21 students $(84 \%)$, as shown in the image below

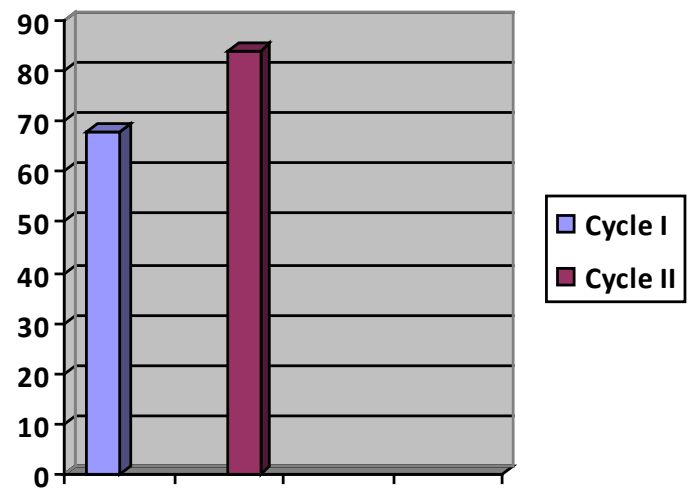

Diagram 3. Comparison of Student Learning Achievement Achieving Minimum Mastery Criteria in Cycle I and II

32 Interview with MIM Students in Pondok Karanganom MIM Class I, March 20, 2019. 
From the results of cycle I and cycle II media drinking straws and number bags have a better impact on increasing the addition of two numbers. Learning becomes fun, is not boring and makes it easy for students to solve problems. Zubaidah Amir and Risnawati argued that one of the external factors that could influence learning was learning media such as teaching aids affecting students' success in learning. Students will tend to succeed if assisted by adequate learning media. ${ }^{33}$ This is indicated by an increase in student learning outcomes that complete the minimum mastery criteria as much as $84 \%$. Therefore, the researcher decides that this class action research stops in the second cycle.

\section{Conclusion}

Based on the results of research and discussion, this research can be concluded that:

1. In learning how to add two numbers with using drinking straws and number bags the teacher can activate students. Learning became not easily bored and students were enthusiastic to use the media with guidance from the teacher. This media can also make it easier for students to work on problems. With the results of the ability of teachers and students in the first cycle $87.5 \%$ and in the second cycle the results of the ability of teachers and students were $100 \%$ and $87.5 \%$.

2. Increased student learning outcomes from cycle I to cycle II, indicated by the number of students who achieved the Minimum completeness Criteria (KKM) from the post-test results in the first cycle reached page 196.
$68 \%$, the second cycle reached $84 \%$. Thus the application of drinking straws media and number bags can improve mathematics learning outcomes in the sum of two class I B MI Muhammadiyah Pondok Karanganom, Klaten academic year 2018/2019.

\section{References}

Abdurrahman, Mulyono, Pendidikan Bagi Anak Berkesulitan Belajar, Jakarta: Rineka Cipta, 2000.

Amir, Zubaidah, dan Risnawati, Psikologi Pembelajaran Matematika, Yogyakarta: Aswaja Pressindo, 2016.

Ernawati, Dwi, “Peran Guru Kelas Dalam Mengatasi Kesulitan Belajar Matematika Pada Siswa Kelas III Di SD Negeri Suryodiningrat I Yogyakarta", Universitas PGRI Yogyakarta, n.d.

Hartiny Sam's, Rosma, Model Penelitian Tindakan Kelas Teknik Bermain Konstuktif Untuk Peningkatan Hasil Belajar Matematika, Yogyakarta: Sukses Offset, 2010.

Heruman, Model Pembelajaran Matematika Di Sekolah Dasar, Bandung: PT. Remaja Rosdakarya, 2017.

Ibrahim, dan Suparni, Pembelajaran Matematika teori dan Aplikasinya, Yogyakarta: SUKA-Press UIN Sunan Kalijaga, 2012.

Mayasa. Media Pembelajaran Sedotan (Dringking Straws) dan Kantong Bilangan, dalam laman m4y-a5a. blogspot.com/2012/04/mediapembelajaran-sedotan-dringkinghtml?m=1 diambil pada 5 Januari 2019 pukul 19:30 WIB

Ratnasari, Devi "Pengaruh Penggunaan Media Kntong Bilangan Terhadap HasilBelajarMatematikapenjumlahan 
116| Hlementitiry Vol. 5 No. 2, July -December 2019

Bilangan Secara Bersusun", Jurnal

Pendidikan Guru Sekolah Dasar Edisi 27

Tahun ke-5 2016.

S. Suriasumantri, Jujun, Filsafat Ilmu Sebuah

Pengantar Populer, Jakarta: Sinar Harapan, 2005.

Yuliawati, Fitri, Jamil Suprihatiningsah, dan M. Agung Rokhimawan, Penelitian Tindakan Kelas Untuk Tenaga Pendidik Prifesional, Yogyakarta: Pedagogia, 2012. 